\title{
Analysis of Accidents Through the Approach of Human Error and Job Safety Analysis (JSA)
}

\author{
Elisabeth Ginting ${ }^{1}$, Mangara M. Tambunan ${ }^{2}$ \\ ${ }^{1,2}$ Departemen Teknik Industri, Fakultas Teknik, Universitas Sumatera Utara, Indonesia \\ ir.elisabethginting@gmail.com \\ araapul tambunan@yahoo.com
}

\begin{abstract}
Accident mainly caused by two factors that is, unsafe action and unsafe condition (Suma'mur:1981). Unsafe action was an act of unsafe done by operator while unsafe condition is the influence of a work environment where having two potentials to causing danger (hazard). Work accident occurred in X Company mainly caused by operator's fault in implementing activity (human error).

The purpose of this research is to analyze the mistake by operators resulting in the accident. The research commenced a preliminary, literature study and collecting data whether it is primary and secondary.

Processing was conducted qualitatively using Systematic Human Error Reduction and Prediction (SHERPA) to know error by operators of the critical that can cause of the accident. Next, quantitatively using Human Error assessment Reduction Technique (HEART) to see how big Human Error Probability (HEP) from their own - operator. The result of qualitative analysis by SHERPA obtained some activity has a probability ordinal who is critical that can cause of the accident .Based on the assessment obtained from the quantitative HEP from their own operator. After analysis human error, then continued to the Job Safety Analysis (JSA) to know danger of work that is undertaken.

The results of the analysis suggest that there is an effort to prevent and to tackle accident is curative and rehabilitative treatments to reduce crash work.
\end{abstract}

Keywords-Human Error, SHERPA, HEART, JSA

\section{INTRODUCTION}

\section{A. Backgrounds}

Work accident is an occurrence of undesired and unplanned action [1]. Accidents in production floor caused by operators less attention to the risks of the activity (unsafe human acts). Operators consider the mistakes become common thing. Did not use personal protective equipment provided by company and the wrong working methods like letting recently opened mold scattered on the production floor that can lead to snag by nails spikes and so on. In fact, operator error or operator negligence can cause work accidents.

CV. $\mathrm{X}$ is a small and medium enterprises (SMEs) engaged in metal processing. The resulting products are products made from metals both iron and aluminum such as frying pan, stone buoys, steam boiler components and so on in accordance with the order given. In its operating activities, CV. X relying on human power as full control with all the limitations that possessed by humans. This causes errors are one of them caused by the man himself (human error).

This study focused on the identification of human error and the consequences resulting from such errors. Rate of human error conducted using Systematic Human Error Reduction and Prediction (SHERPA) which is used to identify errors and done by operator that can cause accidents and Human Assessment and Reduction Technique (HEART) which is used to calculate the Human Error Probability (HEP) so it can be seen how much the probability of operator error that can cause accidents [2]. Furthermore, the identification of the hazards approaches with Job Safety Analysis (JSA). [3]

\section{B. Problem Identification}

Circumstances as a work accident that occurred at $\mathrm{CV}$. $\mathrm{X}$ is caused by many factors, one of the factor is human error accidents caused by operator who often perform actions that potentially lead to accidents and lack of prevention and response to accidents which are applied on the production floor at CV. X.

\section{LITERATURE REVIEW}

\section{A. Occupational Health and Safety}

Safety is the conservation of human life and the maintenance of its effectiveness and the prevention of damage to items / system as per specified requirements [4]. Occupational health is a specialization in the field of medical and its practice that aimed at keeping workers or community workers healthy standard high, either physically or 
mentally with the efforts of preventive and curative, against diseases or health problems were caused by job factors and work environment.

\section{B. Human Error}

Human error can be defined as a fault or a failure to complete a specific task (perform actions that are not permitted) that may interfere with the operation schedule or result in damage to objects, equipment and people. Human error is an act beyond the limits of acceptance or a deviation from the norm, in which the acceptance limit of performance defined by the system.[5]

\section{Hierarchical Task Analysis (HTA)}

Hierarchical Task Analysis (HTA) is one of the methods used in the analysis task. HTA is the method most often used because its application is very detailed, easily and directly on target. Task Analysis (TA) is a formal method to describe and analyze human interaction with the system. Analysis task defines in detail the role of the operator in a system. TA described what the operator needs to do in the shape of physical and cognitive activity to achieve the goals of the system. HTA does not only analyze the actions taken, but also to analyze the purpose and operation of the action, ways in which to achieve the goal. A complex task broken down into operations and sub-operation which would not meet due to poor design or lack of expertise, then filed a solution to the problem. [6]

\section{Systematic Human Error Reduction and Prediction Approach (SHERPA)}

SHERPA developed by Embrey (1986) as a technique for predicting human error is also analyzed the work and identify potential solutions to resolve errors in a structured way. This technique is based on the taxonomy of human error and in its original form is devoted to the psychological mechanism that implicates error. [7]

The procedure must be performed using methods SHERPA method are:

\footnotetext{
1) Hierarchical Task Analysis (HTA) [8]

Preparation of the whole list of work into the HTA diagram

2) Job Classification [9]

HTA diagram then classified into several types of errors
}

that exist such as: Action, Retrieval, Checking, Selection and Information.

3) Human Error Identification [10]
A, Error Action category, by 10 points (A1-A10)
C, Error Checking category, by 6 points (C1-C6)
R, Retrieval Error category, by 3 points (R1-R3)
$\mathrm{S}$, Selection Error category, by 2 points (S1-S2)
I, Error Information category, by 3 points (I1-I3)

4) Analysis of Consequences

At this stage, the preparation of the list most likely consequences if an operator performed work included in this type of error.

5) Analysis of Recovery

Recovery is actions that can be done to correct the error.

6) The assessment of Error Ordinal Probability

Ordinal probability values done in SHERPA method are low, medium and high.

7) Analysis of Critical Level

Errors that is critical given the exclamation point (!) And to errors that are not critical given the dash (-).

8) Strategy to fix error (remedy analysis)

Strategic planning needs to be done in order to reduce error. Strategies can be grouped into four categories: equipment, training, and organizational procedures.

\section{E. Human Error Assessment and Reduction Technique}

\section{(HEART)}

The first function of HEART calculation process is grouping tasks in general categories and value for human unreliability nominal level according to the HEART table generic categories. The HEART technique assumes that any predicted reliability of task performance may be modified according to the presence of the identified EPCs [11]. Next is to identify the conditions that resulted in an error (Error Producing Condition, EPCs) are shown in the form of scenarios that negatively affect human performance [12]. So, HEART is part of the calculation of reliability is defined as how much the operator made a mistake in a task that should be done.

Steps to determine the value of HEP using HEART method are:

1) Identify all types of work to be done by the operators.

2) Categorize action in each work item mistake, one of eight categories in Generic Tact Type.

3) Identification of Error Producing Condition (EPCs) in accordance with the existing scenario at HEART EPCs table and determine the maximum value. 
4) Determine the proportion effect or Assessed Proportion of Effect (APOE) and calculates the value of Assessed Effect (AE) of each EPCs that have been identified using formula:

$\mathrm{AE}_{\mathrm{i}}=(($ Max. Effect -1$) \times \mathrm{APOE})+1$

5) Calculate the total value of AE.

6) Calculate HEP value using formula:

$\mathrm{HEP}=$ HEP Nominal $\times$ AE Total

\section{F. Job Safety Analysis (JSA)}

One way to prevent workplace accident is to establish and develop procedures and train all workers work to implement the working methods efficiently and safely. Develop the correct working procedures is one of the advantages of applying Job Safety Analysis (JSA) which is used to review the working methods and finding danger. JSA is a systematic identification of potential risk in the workplace that can be identified, analyzed and recorded [13]. The steps that must be done in preparing the JSA namely:

1) Choosing a job

A job with poor accident history has a priority and should be analyzed first. In choosing a job that will be analyzed, a department supervisor must meet the following factors: frequency of accidents, the level of injury that causes disability, abuse potential, new jobs and approaching risk.

2) Divide the work in work order

To divide the work, choose the right worker to make observations.

3) Risk identification and potential workplace accident The next step to develop JSA is identification all of the risk including every steps.

4) Developing the solutions

The last step in JSA is developing the safety work procedure for preventing accident potential. [14]

\section{RESEARCH METHODOLOGY}

The research methodology is the steps to be taken in the study to achieve the desired objectives. To achieve the objectives that must be done are:

1) Data collection for the work stations

Data collection for the work stations in the form of a sequence of production processes, error data and qualitative data about the work environment.

2) Preparation of the Hierarchical Task Analysis (HTA)
3) Preparation of the Systematic Human Error Reduction and Prediction Approach (SHERPA).

4) Preparation by Human Error Assessment and Reduction Technique (HEART).

5) The safety analysis jobs using the JSA.

6) Proposed improvement.

\section{RESULT AND DISCUSSION}

Activities data done by operator carried out as follows:

A. Operators in the metal melting activities (Task 1):

1) Taking used metals

2) Incorporating these metals into the furnace

3) Stirring the liquid metal

4) Checking the state of the liquid metal

B. Operators in the activity of fire ignition axis (Task 2)

1) Turn on the source of fire

2) Check and adjust the flame

3) Unscrew the bottom of the furnace to remove the liquid metal

4) Pouring powder to separate the slag

5) Discard slag in the container

C. Operators of printing activity (Task 3)

1) Adjust the position of the metal container for carrying liquids

2) Bring the liquid metal into the mold

3) Pouring molten metal into the mold

4) Checking the mold that has been filled

D. The operator in the finishing section (Task 4)

1) Opening the mold that has been held for 1 night

2) Release a printout of the mold

3) Cleaning printout of stuck sand

4) Chiseling or grinding mold results

SHERPA data processing begins with making HTA that can be seen in Figure 1. 


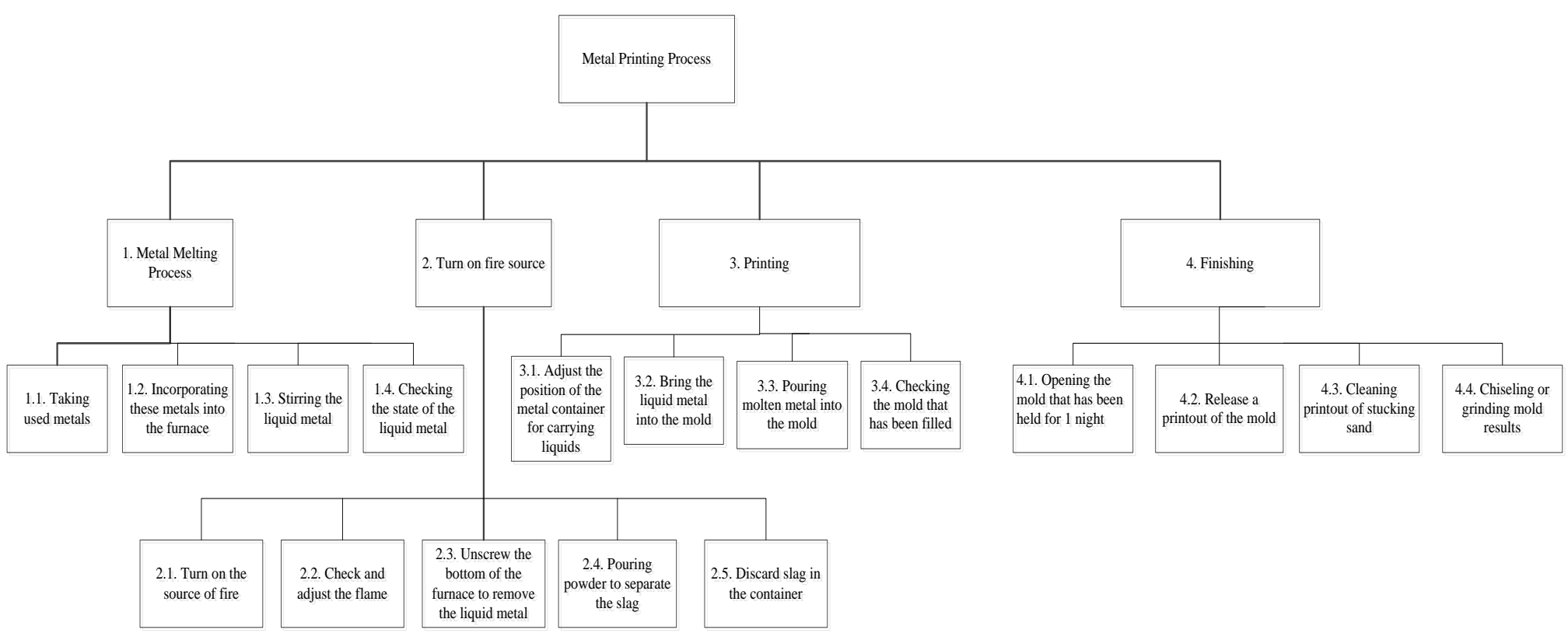

Fig.1 Hierarchical Task Analysis (HTA) of Metal Printing Process

After HTA made the lowest level of HTA is used as input to the table SHERPA. SHERPA table can be seen in Table 1. [15]

TABLE I. SHERPA

\begin{tabular}{|c|c|c|c|c|c|c|}
\hline Job Step & $\begin{array}{l}\text { Type } \\
\text { Mode }\end{array}$ & $\begin{array}{l}\text { Error Possible } \\
\text { Explanations }\end{array}$ & $\begin{array}{l}\text { Consequences } \\
\text { Analysis }\end{array}$ & Recovery Analysis & $\begin{array}{l}\text { Probability } \\
\text { Ordinal } \\
\text { Value (P) }\end{array}$ & $\begin{array}{l}\text { Critical } \\
\text { Value } \\
\text { (C) }\end{array}$ \\
\hline $\begin{array}{l}\text { 1.1. Taking used } \\
\text { metals }\end{array}$ & A7 & Did not use gloves & $\begin{array}{l}\text { Hands can be } \\
\text { exposed sharp metals }\end{array}$ & $\begin{array}{l}\text { The wound was } \\
\text { cleaned and treated }\end{array}$ & $\mathrm{H}$ & $!$ \\
\hline $\begin{array}{l}\text { 1.2. Incorporating } \\
\text { these metals into the } \\
\text { furnace }\end{array}$ & A7 & $\begin{array}{l}\text { Did not wear clothes } \\
\text { and gloves }\end{array}$ & $\begin{array}{l}\text { Can be exposed to the } \\
\text { liquid metal splashes }\end{array}$ & $\begin{array}{l}\text { Splashes as soon as } \\
\text { possible wiped and } \\
\text { washed with water }\end{array}$ & $\mathrm{H}$ & $!$ \\
\hline $\begin{array}{l}\text { 1.3. Stirring the } \\
\text { liquid metal }\end{array}$ & A7 & $\begin{array}{l}\text { Did not wear clothes } \\
\text { and gloves }\end{array}$ & $\begin{array}{l}\text { The liquid metal can } \\
\text { be splashed onto the } \\
\text { operator body }\end{array}$ & $\begin{array}{l}\text { Splashes as soon as } \\
\text { possible wiped and } \\
\text { washed with water }\end{array}$ & $\mathrm{H}$ & $!$ \\
\hline $\begin{array}{l}\text { 1.4. Checking the } \\
\text { state of the liquid } \\
\text { metal }\end{array}$ & $\mathrm{C} 3$ & $\begin{array}{l}\text { Did not wear clothes } \\
\text { and gloves }\end{array}$ & $\begin{array}{l}\text { The liquid metal can } \\
\text { be splashed onto the } \\
\text { operator body }\end{array}$ & $\begin{array}{l}\text { Splashes as soon as } \\
\text { possible wiped and } \\
\text { washed with water } \\
\end{array}$ & $\mathrm{H}$ & $!$ \\
\hline $\begin{array}{l}\text { 2.1. Turn on the } \\
\text { source of fire }\end{array}$ & A7 & Did not use gloves & $\begin{array}{l}\text { Can be exposed to } \\
\text { flame and dust }\end{array}$ & $\begin{array}{l}\text { As soon as possible } \\
\text { wiped with clean water }\end{array}$ & $\mathrm{H}$ & $!$ \\
\hline $\begin{array}{l}\text { 2.2. Check and } \\
\text { adjust the flame }\end{array}$ & $\mathrm{C} 3$ & $\begin{array}{l}\text { Holding iron setting } \\
\text { fire without gloves }\end{array}$ & Hands can be burned & $\begin{array}{l}\text { Operator releases the } \\
\text { handle iron for a while }\end{array}$ & M & - \\
\hline $\begin{array}{l}\text { 2.3. Unscrew the } \\
\text { bottom of the } \\
\text { furnace to remove } \\
\text { the liquid metal }\end{array}$ & A7 & Did not use gloves & Hands can be burned & $\begin{array}{l}\text { Remove the handle of } \\
\text { the container briefly } \\
\text { and discharge } \\
\text { accommodated }\end{array}$ & M & - \\
\hline $\begin{array}{l}\text { 2.4. Adjust the } \\
\text { position of the } \\
\text { container where the } \\
\text { liquid metal is } \\
\text { poured }\end{array}$ & A10 & Did not use gloves & $\begin{array}{l}\text { Can be exposed to } \\
\text { heat from fire }\end{array}$ & Use tools & $\mathrm{M}$ & - \\
\hline $\begin{array}{l}\text { 2.5. Pouring powder } \\
\text { to separate the slag }\end{array}$ & A1 & $\begin{array}{l}\text { Pouring powder the } \\
\text { dirt with less control }\end{array}$ & $\begin{array}{l}\text { Flying powder and } \\
\text { strong liquid splashes }\end{array}$ & $\begin{array}{l}\text { Pour the powder slowly } \\
\text { so that the liquid did } \\
\text { not splashes }\end{array}$ & $\mathrm{H}$ & $!$ \\
\hline
\end{tabular}




\begin{tabular}{|c|c|c|c|c|c|c|}
\hline $\begin{array}{l}\text { 2.6. Discard slag in } \\
\text { the container }\end{array}$ & A7 & $\begin{array}{l}\text { Disposing of metal } \\
\text { impurities to any } \\
\text { place around the } \\
\text { furnace }\end{array}$ & $\begin{array}{l}\text { Slag scattered and } \\
\text { expose on foot }\end{array}$ & $\begin{array}{l}\text { If affected the leg, flush } \\
\text { with clean water }\end{array}$ & $\mathrm{H}$ & ! \\
\hline $\begin{array}{l}\text { 3.1. Adjust the } \\
\text { position of the metal } \\
\text { container for } \\
\text { carrying liquids }\end{array}$ & A10 & Did not use gloves & $\begin{array}{l}\text { Exposed heat from } \\
\text { fire source and } \\
\text { trampled by slag }\end{array}$ & $\begin{array}{l}\text { Stay away from fire } \\
\text { sources }\end{array}$ & $\mathrm{M}$ & - \\
\hline $\begin{array}{l}\text { 3.2. Bring the liquid } \\
\text { metal into the mold }\end{array}$ & A7 & $\begin{array}{l}\text { Did not use gloves } \\
\text { and footwear }\end{array}$ & $\begin{array}{l}\text { Hands become } \\
\text { burned and can be } \\
\text { exposed to liquid } \\
\text { droplets }\end{array}$ & $\begin{array}{l}\text { Remove the handle of } \\
\text { the container briefly } \\
\text { and discharge } \\
\text { accommodated }\end{array}$ & L & ! \\
\hline $\begin{array}{l}\text { 3.3. Pouring molten } \\
\text { metal into the mold }\end{array}$ & A1 & $\begin{array}{l}\text { Pouring the liquid } \\
\text { metal with less } \\
\text { control so that spilled }\end{array}$ & $\begin{array}{l}\text { Can be exposed to } \\
\text { liquid droplets }\end{array}$ & $\begin{array}{l}\text { As soon as possible } \\
\text { wiped with clean water }\end{array}$ & M & $!$ \\
\hline $\begin{array}{l}\text { 3.4. Checking the } \\
\text { mold that has been } \\
\text { filled }\end{array}$ & $\mathrm{C} 3$ & $\begin{array}{l}\text { Holding mold that } \\
\text { has been filled } \\
\text { without gloves } \\
\end{array}$ & Hands can be burned & $\begin{array}{l}\text { Operator releases the } \\
\text { handle iron }\end{array}$ & $\mathrm{L}$ & - \\
\hline $\begin{array}{l}\text { 4.1. Opening the } \\
\text { mold that has been } \\
\text { held for } 1 \text { night }\end{array}$ & A7 & Did not use footwear & $\begin{array}{l}\text { Can be exposed to } \\
\text { hot sand }\end{array}$ & $\begin{array}{l}\text { Wiped the foot and stop } \\
\text { for a while }\end{array}$ & M & - \\
\hline $\begin{array}{l}\text { 4.2. Release a } \\
\text { printout of the mold }\end{array}$ & A10 & $\begin{array}{l}\text { Provide prints that } \\
\text { have been opened } \\
\text { scattered }\end{array}$ & $\begin{array}{l}\text { Can be stumble by } \\
\text { nails and wood }\end{array}$ & $\begin{array}{l}\text { The wound was } \\
\text { cleaned and antiseptic } \\
\text { was given }\end{array}$ & $\mathrm{H}$ & $!$ \\
\hline $\begin{array}{l}\text { 4.3. Cleaning } \\
\text { printout of stucking } \\
\text { sand }\end{array}$ & A7 & $\begin{array}{l}\text { Talk and laugh did } \\
\text { not wear a mask }\end{array}$ & $\begin{array}{l}\text { Sand dust can be } \\
\text { inhaled by operators }\end{array}$ & $\begin{array}{l}\text { Stop for a while and } \\
\text { use the mask }\end{array}$ & M & - \\
\hline $\begin{array}{l}\text { 4.4. Chiseling or } \\
\text { grinding mold results }\end{array}$ & A7 & $\begin{array}{l}\text { Smoking while } \\
\text { grinding so the chisel } \\
\text { eye run off target }\end{array}$ & $\begin{array}{l}\text { Chisel eyes can } \\
\text { exposed the } \\
\text { operator's hands }\end{array}$ & $\begin{array}{l}\text { The wound was } \\
\text { cleaned and antiseptic } \\
\text { was given }\end{array}$ & $\mathrm{H}$ & $!$ \\
\hline
\end{tabular}

Determination of Human Error Probability using HEART method

TABLE II

HEP CALCULATION TASK 1

\begin{tabular}{|l|l|l|l|l|}
\hline $\begin{array}{l}\text { No. } \\
\text { Task }\end{array}$ & GTT & $\begin{array}{l}\text { HEP } \\
\text { Nominal }\end{array}$ & $\begin{array}{l}\text { AE } \\
\text { Total }\end{array}$ & HEP \\
\hline 1.1 & G & 0,0004 & 46,08 & 0,0184 \\
\hline 1.2 & G & 0,0004 & 46,08 & 0,0184 \\
\hline 1.3 & G & 0,0004 & 46,08 & 0,0184 \\
\hline 1.4 & F & 0,003 & 46,08 & 0,1382 \\
\hline
\end{tabular}

TABLE III

HEP CALCULATION TASK 2

\begin{tabular}{|l|l|l|l|l|}
\hline $\begin{array}{l}\text { No. } \\
\text { Task }\end{array}$ & GTT & $\begin{array}{l}\text { HEP } \\
\text { Nominal }\end{array}$ & $\begin{array}{l}\text { AE } \\
\text { Total }\end{array}$ & HEP \\
\hline 2.1 & G & 0,0004 & 13,91 & 0,0055 \\
\hline 2.2 & F & 0,003 & 13,91 & 0,0417 \\
\hline 2.3 & G & 0,0004 & 13,91 & 0,0055 \\
\hline 2.4 & G & 0,0004 & 13,91 & 0,0055 \\
\hline 2.5 & G & 0,0004 & 13,91 & 0,0055 \\
\hline 2.6 & G & 0,0004 & 13,91 & 0,0055 \\
\hline
\end{tabular}

can be seen in Table 2 to Table 5 for each task.

TABLE IV

HEP CALCULATION TASK 3

\begin{tabular}{|l|l|l|l|l|}
\hline $\begin{array}{l}\text { No. } \\
\text { Task }\end{array}$ & GTT & $\begin{array}{l}\text { HEP } \\
\text { Nominal }\end{array}$ & $\begin{array}{l}\text { AE } \\
\text { Total }\end{array}$ & HEP \\
\hline 3.1 & G & 0,0004 & 69,44 & 0,0277 \\
\hline 3.2 & G & 0,0004 & 69,44 & 0,0277 \\
\hline 3.3 & G & 0,0004 & 69,44 & 0,0277 \\
\hline 3.4 & F & 0,003 & 69,44 & 0,2083 \\
\hline
\end{tabular}

TABLE V

HEP CALCULATION TASK 4

\begin{tabular}{|l|l|l|l|l|}
\hline $\begin{array}{l}\text { No. } \\
\text { Task }\end{array}$ & GTT & $\begin{array}{l}\text { HEP } \\
\text { Nominal }\end{array}$ & $\begin{array}{l}\text { AE } \\
\text { Total }\end{array}$ & HEP \\
\hline 4.1 & G & 0,0004 & 65,95 & 0,0279 \\
\hline 4.2 & G & 0,0004 & 65,95 & 0,0279 \\
\hline 4.3 & G & 0,0004 & 65,95 & 0,0279 \\
\hline 4.4 & G & 0,0004 & 65,95 & 0,0279 \\
\hline
\end{tabular}

In determining the hazard identification can used Job Safety Analysis which can be seen in Table 6 . 
TABLE VI.

LIST OF HAZARDS IDENTIFICATION WITH JSA

\begin{tabular}{|c|c|c|c|c|}
\hline No & Task & Job Description & $\begin{array}{l}\text { Hazards } \\
\text { Identification }\end{array}$ & Solution \\
\hline \multirow{4}{*}{1.} & \multirow{4}{*}{$\begin{array}{l}\text { Metal Melting } \\
\text { Process }\end{array}$} & Taking used metals & $\begin{array}{l}\text { Metal can hurt the } \\
\text { hands }\end{array}$ & \multirow{4}{*}{$\begin{array}{l}\text { 1. Use of PPE such as helmets, work } \\
\text { outfit, boots, and gloves } \\
\text { 2. PPE is used can improve the } \\
\text { working procedures as well stir the } \\
\text { liquid metal }\end{array}$} \\
\hline & & $\begin{array}{l}\text { Incorporating these metals } \\
\text { into the furnace }\end{array}$ & $\begin{array}{l}\text { Can be exposed to } \\
\text { the liquid metal } \\
\text { splashes }\end{array}$ & \\
\hline & & Stirring the liquid metal & $\begin{array}{l}\text { The liquid metal } \\
\text { can be splashed } \\
\text { onto the operator } \\
\text { body }\end{array}$ & \\
\hline & & Check and adjust the flame & $\begin{array}{l}\text { Hands can be } \\
\text { burned }\end{array}$ & \\
\hline \multirow{5}{*}{2} & \multirow{5}{*}{$\begin{array}{l}\text { Ignition of fire } \\
\text { sources }\end{array}$} & Turn on the source of fire & $\begin{array}{l}\text { Can be exposed to } \\
\text { flame and dust }\end{array}$ & \multirow{5}{*}{$\begin{array}{l}\text { 1. Use of PPE such as helmets, work } \\
\text { outfit, boots and gloves. } \\
\text { 2. Use tools such as long-handled } \\
\text { spoon to sprinkle the powder dirt. } \\
\text { 3. Creation of a faucet on the bottom } \\
\text { of the furnace to reduce the } \\
\text { impact of accidents. }\end{array}$} \\
\hline & & Hands can be burned & $\begin{array}{l}\text { Hands can be } \\
\text { burned }\end{array}$ & \\
\hline & & $\begin{array}{l}\text { Can be exposed to heat from } \\
\text { fire }\end{array}$ & $\begin{array}{l}\text { Flying powder and } \\
\text { strong liquid } \\
\text { splashes }\end{array}$ & \\
\hline & & $\begin{array}{l}\text { Slag scattered and expose on } \\
\text { foot }\end{array}$ & $\begin{array}{l}\text { Check and adjust } \\
\text { the flame }\end{array}$ & \\
\hline & & $\begin{array}{l}\text { Unscrew the bottom of the } \\
\text { furnace to remove the liquid } \\
\text { metal }\end{array}$ & $\begin{array}{l}\text { Adjust the position } \\
\text { of the container } \\
\text { where the liquid } \\
\text { metal is poured }\end{array}$ & \\
\hline & & Discard slag in the container & $\begin{array}{l}\text { Slag scattered and } \\
\text { expose on foot }\end{array}$ & \\
\hline \multirow{4}{*}{3} & \multirow{4}{*}{ Molding } & $\begin{array}{l}\text { Adjust the position of the } \\
\text { metal container for carrying } \\
\text { liquids }\end{array}$ & $\begin{array}{l}\text { Bring the liquid } \\
\text { metal into the mold }\end{array}$ & \multirow{4}{*}{$\begin{array}{l}\text { 1. Use of PPE such as helmets, work } \\
\text { outfit, boots and gloves. } \\
\text { 2. Use the tools work like a funnel to } \\
\text { facilitate the work. }\end{array}$} \\
\hline & & $\begin{array}{l}\text { Pouring molten metal into } \\
\text { the mold }\end{array}$ & $\begin{array}{l}\text { Checking the mold } \\
\text { that has been filled }\end{array}$ & \\
\hline & & $\begin{array}{l}\text { Exposed heat from fire } \\
\text { source and trampled by slag }\end{array}$ & $\begin{array}{l}\text { Hands become } \\
\text { burned and can be } \\
\text { exposed to liquid } \\
\text { droplets }\end{array}$ & \\
\hline & & $\begin{array}{l}\text { Can be exposed to liquid } \\
\text { droplets }\end{array}$ & $\begin{array}{l}\text { Hands can be } \\
\text { burned }\end{array}$ & \\
\hline \multirow{4}{*}{4} & \multirow{4}{*}{ Finishing } & $\begin{array}{l}\text { Opening the mold that has } \\
\text { been held for } 1 \text { night }\end{array}$ & $\begin{array}{l}\text { Release a printout } \\
\text { of the mold }\end{array}$ & \multirow{4}{*}{$\begin{array}{l}\text { 1. Use of PPE such as helmets, } \\
\text { work outfit, boots and gloves. } \\
\text { 2. Fix the working procedure such } \\
\text { as do not smoke when working }\end{array}$} \\
\hline & & $\begin{array}{l}\text { Cleaning printout of stucking } \\
\text { sand }\end{array}$ & $\begin{array}{l}\text { Chiseling or } \\
\text { grinding mold } \\
\text { results }\end{array}$ & \\
\hline & & Can be exposed to hot sand & $\begin{array}{l}\text { Can be stumble by } \\
\text { nails and wood }\end{array}$ & \\
\hline & & $\begin{array}{l}\text { Sand dust can be inhaled by } \\
\text { operators }\end{array}$ & $\begin{array}{l}\text { Chisel eyes can } \\
\text { exposed the } \\
\text { operator's hands }\end{array}$ & \\
\hline
\end{tabular}




\section{E.Conclusion and Recommendation}

Based on analysis of the qualitative approach Systematic Human Error Reduction and Prediction Approach (SHERPA) the obtained work that is critical that cause workplace accidents are:

1) Operators take the used metals without gloves

2) Operators incorporate the used metal into the furnace did not using clothes and gloves.

3) Operators stirring the liquids without clothes and gloves

4) Operators check the state of the liquid metal without clothes, gloves and so on.

As for strategies to improve the error is as

follows:

1) Supervising the use of Personal Protective Equipment.

2) Supervise the work methods of production floor

3) Provide a warning to the operator about the importance of workplace safety through warning signs and so on.

Based on analysis of the HEART qualification FTA is influenced by EPCs, then in task 1, operators who perform activities HEP melting metal has amounted to 0.185 , or approximately $18.5 \%$ with description of the activities that take metals, metals entering into the furnace, stirring the liquid metal and check the state of the liquid metal. Human Error Probability (HEP) indicates the gauge of the mistakes made by each operator in the work activity that can cause accidents.

JSA is based on identifying hazards to a work conducted found potential hazards or accidents that may occur are:

1) Trampled nails and other objects were strewn on the floor production.

2) Burns from contact with liquids metals

3) Dust can be inhaled and enter the eye

4) Piles of wood are strewn can lead to accidents such as snagging, trampled nails and so on.
5) Crust strewn metal can also cause accidents such as trampled and burns.

The solution given to identification the hazards are:

1) Always use Personal Protective Equipment (PPE) such as helmets, work outfit, boots, gloves, masks and goggles.

2) Fix the system and work procedures to prevent risk.

3) Use the tools that can be used for certain activities.

\section{REFERENCES}

[1] Dhillon, Balbir S., 1987, Human Reliability: With Human Factors. Pergamin Press,Exeter, United Kingdom.

[2] Pasquale, Valentina Di, et al, 2016, Integration of Learning and Forgetting Processes with the SHERPA Model. Science Direct Journal, Fisciano, Italy.

[3] Shan, Khun Lun, et al, 2011, A Safety Approach to Predict Human Error in Critical Flight Task. Science Direct Journal, Beijing, China.

[4] Dhillon, Balbir S., 2010, Mine Safety A Modern Approach. Springer, Ottawa, Canada.

[5] Park, Kyung S, 1997, Human Error. Handbook of Human Factors and Ergonomics, CRC Press, Washington DC, United States.

[6] Annet, J, 2002, Hierarchical Task Analysis. Handbook of Human Factors and Ergonomic Methods, CRC Press, Washington DC, United States.

[7] Stanton, N.A., 2002, Systematic Human Error Reduction and Prediction Approach. Handbook of Human Factors and Ergonomic Methods, CRC Press, Washington DC, United States.

[8] Kirwan, B., Ainsworth, 1992, A Guide to Task Analysis. Taylor \& Francis, London, United Kingdom.

[9] Stanton, Neville A., 2013, Human Factors Methods, CRC Press, Washington DC, United States.

[10] Nemeth, Christopher P., 2004, Human Factors Method for Design, CRC Press, Washington DC, United States.

[11] Castiglia, Francesco, et al, 2014, THERP and HEART Integrated Methodology for Human Error Assessment, Science Direct Journal, Palermo, Italy

[12] Bell, Julie, Justin Holroyd, 2009, Review of Human Reliability Assessment Methods, HSE Books, United Kingdom

[13] Thulasi, Rajan R., 2016, Proactive Human Behavior Based Safety Analysis in Industry. International Journal of Engineering Research and General Science Volume 4, Issue 4.

[14] Glenn, David D., 2011, Job Safety Analysis Its Role Today. ASSE Journal, Chicago, United States.

[15] Lane, R., et al, 2006, Applying Hierarchical Task Analysis to Medication Administration Errors. Science Direct, London, United Kingdom. 